http://dx.doi.org/10.11646/zootaxa.3802.2.1

http://zoobank.org/urn:lsid:zoobank.org:pub:20400951-A62C-49FD-9D70-3FE54557E5D8

\title{
New species and new records of eunicids (Polychaeta, Eunicidae) from Taiwan
}

\author{
PAN-WEN HSUEH ${ }^{1,3} \&$ YAN-HUEI LI ${ }^{2}$ \\ ${ }^{1}$ Department of Life Sciences, National Chung Hsing University, Taichung, Taiwan 402, R.O.C. \\ ${ }^{2}$ Biodiversity Research Center, Academia Sinica, Taipei, Taiwan 115, R.O.C. \\ ${ }^{3}$ Corresponding author. E-mail: pwhsueh@dragon.nchu.edu.tw
}

\begin{abstract}
Seven species of eunicids were found from rocky intertidal and shallow subtidal habitats on the coasts of Taiwan. These polychaetous worms belong to two genera, Eunice Cuvier, 1817 and Nicidion Kinberg, 1865. Among them, five species are new to science, namely Eunice jihueiensis sp. nov., Eunice reticulata sp. nov., Eunice shihmenensis sp. nov., Eunice taoi sp. nov., and Nicidion megabalanicola sp. nov., Eunice annulicirrata Miura, 1986 and Eunice dilatata Grube, 1877, are documented for the first time from this geographic region. A key to the genus and species of these eunicids is provided.
\end{abstract}

Key words: taxonomy, intertidal and shallow water eunicid polychaetes

\section{Introduction}

The genus Eunice Cuvier, 1817 is one of the most highly diversified polychaete groups with 250 plus species worldwide (Fauchald \& Bella 2013), which occupies all marine benthic environments and is especially common in tropical shallow seas (Fauchald 1992). Despite its abundance in tropical shallow marine habitats, the taxonomic study of this polychaete genus in Taiwan, a geographic region on the Tropic of Cancer, is virtually not existent. Nevertheless, over hundred specimens of Eunice were accumulated over the past three decades by curators at National Museum of Natural Sciences, Taiwan as well as by authors of the present study. A taxonomic study of this material was undertaken by the authors.

To study this highly diversified polychaete group, Hartman (1944) and Fauchald (1970) developed a grouping scheme on the basis of the colour and dentations of the subacicular hooks and the distribution pattern of the branchiae. Hartman (1944) divided members of the genus into four groups on the basis of the subacicular colouration. Fauchald (1970) suggested that these four groups could each be subdivided into five subgroups by the distribution pattern of the branchiae. Fauchald (1992) added several categories to further divide a given group into subgroups or special groups (i.e., the absence or presence of articulation on peristomial cirri for A-1 group; see details in Tables 20 to 53).

The systematics of Eunice has been confused for decades. It was once used interchangeably with Leodice Savigny in Lamarck, 1818 (Zanol et al. 2014), and Nicidion Kinberg, 1865 was considered as a subgenus of Eunice (Fauchald 1970). During the late $20^{\text {th }}$ and early $21^{\text {th }}$ century, the latter two genera were still regarded as synonyms of Eunice (Fauchald 1992; Zanol et al. 2010). On the basis of a recent molecular phylogeny study on the family Eunicidae Berthold, 1827, Zanol et al. (2014) suggested Leodice and Nicidion are valid genera and subsequently transferred some of Eunice spp. to these newly re-erected genera.

The present study follows the diagnosis of Eunice and Nicidion given by Fauchald (1992) and Zanol et al. (2014) to split the specimens collected from Taiwan and recognizes six Eunice species and one Nicidion species. Of these Eunice species, four are new to science, and two are new records for the region. The Nicidion species is also new to science. The present study describes and reports these eunicids and provides a key to these genera and species. 


\section{Acknowledgements}

We appreciate valuable comments of Dr. P. A. Hutchings and two anonymous reviewers for improving our manuscript. This study is supported by grant from the National Science Council, Taiwan, to PWH (NSC95-2621B-005-008).

\section{References}

Amoureux, L. (1977) Annélides Polychtes profondes de Madagascar. Description de deux nouvelles espces (Collections Crosnier et Jouannic). Bulletin du Muséum d'Histoire Naturelle, France, 3e serie (Zoology.), 495, 1093-1109.

Ardila, N.E., Fauchald, K. \& Lattig, P. (2005) Eunice colombia (Eunicidae: Polychaeta), a new species from the southern Caribbean. Proceedings of the Biological Society of Washington, 118, 259-263. http://dx.doi.org/10.2988/0006-324x(2005)118[259:ecepan]2.0.co;2

Carrera-Parra, L.F. \& Salazar-Vallejo, S.I. (1998) A new genus and 12 new species of Eunicidae (Polychaeta) from the Caribbean Sea. Journal of the Marine Biological Association of the United Kingdom, 78, 145-182. http://dx.doi.org/10.1017/s0025315400040005

Carrera-Parra, L.F. \& Salazar-Vallejo, S.I. (2011) Redescriptions of Eunice filamentosa and E. denticulate and description of $E$. tovarae n. sp. (Polychaeta: Eunicidae), highlighted with morphological and molecular data. Zootaxa, 2880, 51-64.

Fauchald, K. (1970) Polychaetous annelids of the families Eunicidae, Lumbrineridae, Iphitimidae, Arabellidae, Lysaretidae and Dorvilleidae from western Mexico. Allan Hancock Monographs in Marine Biology, 5, 1-335.

Fauchald, K. (1977) The polychaete worms: Definitions and keys to the orders, families and genera. Natural History Museum of Los Angeles County and Los Angeles, $188 \mathrm{pp}$.

Fauchald, K. (1986) Review of the types and key to the species of Eunice (Eunicidae: Polychaeta) from the Australian Region. Records of the Australian Museum, 38, 241-262. http://dx.doi.org/10.3853/j.0067-1975.38.1986.182

Fauchald, K. (1992) A review of the genus Eunice (Eunicidae: Polychaeta) based upon type material. Smithsonian Contributions to Zoology, 523, 1-422. http://dx.doi.org/10.5479/si.00810282.523

Fauchald, K. \& Bellan, G. (2013) Eunice Cuvier, 1817. In: Read, G. \& Fauchald, K. (Eds.) (2013) World Polychaeta database. Available from: http://www.marinespecies.org/ (accessed 14 April 2014)

Grube, A.E. (1877) Anneliden-Ausbeute S.M.S. Gazelle. Monatsbericht der Koniglich Preussischer Akademie der Wissenschaften zu Berlin, 1877, 509-554.

Hanley, J.R. (1986) Co-operative effort in a new species of tube dwelling worm, Eunice metatropos (Polychaeta: Eunicidae). The Beagle, Occasional Papers of the Northern Territory Museum of Arts and Sciences, 3, 215-221.

Hartman, O. (1944) Polychaetous Annelids. Part V. Eunicea. Allan Hancock Pacific Expeditions, 10, 1-237.

Hartmann-Schröder, G. (1998) Remarks on Tibiana and description of species Eunice with zigzag-shaped tubes (Polychaeta: Eunicidae). Mitteilungen aus dem Hamburgischen zoologischen Museum und Institut, 95, 45-58.

Hartmann-Schröder, G. \& Zibrowius, H. (1998) Polychaeta associated with Antipatharia (Cnidaria: Anthozoa): description of Polynoidae and Eunicidae. Mitteilungen aus dem Hamburgischen Zoologischen Museum und Institut, 95, $29-44$.

Imajima, M. (2006) Polychaetous Annelids from Sagami Bay and the Sagami Sea, Central Japan. Memoirs of the National Science Museum (Tokyo), 40, 317-408.

Imajima, M. (2007) Annelida, Polychaeta III. Seibutsu Kenkyusha Co., Ltd., Tokyo, 499 pp. [in Japanese]

Imajima, M. \& Hartman, O. (1964) Polychaetes of Japan. Part II. Allan Hancock Foundation Publications. Occasional Papers, 16, 239-452.

Kurt Şahin, G. \& Çınar, M.E. (2009) Eunicidae (Polychaeta) species in and around İskenderun Bay (Levantine Sea, Eastern Mediterranean) with a new alien species for the Mediterranean Sea and a re-description of Lysidice collaris. Turkish Journal of Zoology, 33, 331-347.

Lechapt, J.-P. (1992) Description d'une nouvelle espèce d'Eunice (Polychaeta, Eunicidae) des zones bathyales du Pacifique. Bulletin du Muséum d'Histoire Naturelle, Paris, Series 4, 14, 75-80.

León-González, J.A.de. (1988) A new eunicid polychaete from the Caribbean coast of Mexico. Revista de Biologia Tropical, $36,75-79$.

León-González, J.A.de, Rivera, C.G. \& Romero, M.Y. (2004) Sublittoral Eunicidae and Onuphidae (Polychaeta) from soft bottom off El Salvador, eastern Pacific. Journal of the Marine Biological Association of the United Kingdom, 84, 93-101.

Lu, H. \& Fauchald, K. (1998) Description of Eunice weintraubi and E. wui, two new species of eunicid polychaetes from northern Gulf of Mexico. Proceedings of the Biological Society of Washington, 111, 230-240.

Lu, H. \& Fauchald, K. (2000) A phylogenetic and biogeographic study of Euniphysa (Eunicidae, Polychaeta). Journal of Natural History, 34, 997-1044. http://dx.doi.org/10.1080/00222930050020113

Miura, T. (1977) Eunicid Polychaetous Annelids from Japan- I. La mer (Bulletin de la Société franco-japonaise 
d'océanographie), 15, 1-20.

Miura, T. (1986) Japanese Polychaetes of the genera Eunice and Euniphysa: Taxonomy and branchial distribution patterns. Publication of the Seto Marine Biological Laboratory, 31, 269-325.

Miura, T. (1987) New or little known species of the family Eunicidae (Annelida, Polychaeta) from Japan. Proceedings of the Japanese Society of Systematic Zoology, 36, 1-9.

Nogueira, J.M.M., Steiner, T.M. \& Amaral, A.C.Z. (2001) Descriptions of two new species of Eunice Cuvier, 1817 (Polychaeta: Eunicidae) from coastal islands of the State of Sao Paulo, Brazil. Scientia Marina, 65, 47-58. http://dx.doi.org/10.3989/scimar.2001.65n147

Orensanz, J.M. (1990) The Eunicemorph polychaete annelids from Antarctic and Subantarctic Seas. With addenda to the Eunicemorpha of Argentina, Chile, New Zealand, Australia, and the Southern Indian Ocean. Antarctic Research Series, $52,1-183$. http://dx.doi.org/10.1029/ar052p0001

Orrhage, L. (1995) On the innervation and homologues of the anterior end appendages of the Eunicea (Polychaeta), with a tentative outline of the fundamental constitution of the cephalic nervous system of the polychaetes. Acta Zoologica (Stockholm), 76, 229-248. http://dx.doi.org/10.1111/j.1463-6395.1995.tb00996.x

Wu, X., Sun, R. \& Liu, R. (2013a) A new species of Eunice (Polychaeta: Eunicidae) from Hainan Island, South China Sea. Chinese Journal of Oceanology and Limnology, 31, 134-139. http://dx.doi.org/10.1007/s00343-013-2014-5

Wu, X., Sun, R., Liu, R. \& Xu, K. (2013b) Two new species of Eunice Cuvier, 1817 (Polychaeta, Eunicidae) from the coral reefs of Hainan Island with a key to 16 species of Eunice from China seas. Zootaxa, 3652 (2), 249-264. http://dx.doi.org/10.11646/zootaxa.3652.2.3

Zanol, J., Fauchald, K. \& Paiva, P.C. (2007) A phylogenetic analysis of the genus Eunice (Eunicidae, Polychaete, Annelida). Zoological Journal of the Linnaean Society, 150, 413-434. http://dx.doi.org/10.1111/j.1096-3642.2007.00302.x

Zanol, J., Halanych, K.M. \& Fauchald, K. (2014) Reconciling taxonomy and phylogeny in the bristleworm family Eunicidae (Polychaete, Annelida). Zoologica Scripta, 42, 79-100. http://dx.doi.org/10.1111/zsc.12034

Zanol, J., Paiva, P.C. \& Attolini, F.D. (2000) Eunice and Palola (Eunicidae: Polychaeta) from the eastern Brazilian Coast $\left(13^{\circ} 00^{\prime}-22^{\circ} 30^{\prime} \mathrm{S}\right)$. Bulletin of Marine Science, 67, 449-464.

Zanol, J., Halanych, K.M., Struck, T.H. \& Fauchald, K. (2010) Phylogeny of the bristle worm family Eunicidae (Eunicida, Annelida) and the phylogenetic utility of noncongruent $16 \mathrm{~S}$, COI and $18 \mathrm{~S}$ in combined analyses. Molecular Phylogenetics and Evolution, 55, 660-676.

http://dx.doi.org/10.1016/j.ympev.2009.12.024

\section{APPENDIX}

Key to the genus and species of eunicids of Taiwan (modified from Zanol et al. 2014)

1. Mandibles flat, MxVI absent. Subacicular hook darkest shade closest to distal half or end along the whole body. Presence of hammer-headed superior aciculae and mucronate inferior aciculae..... . Genus Nicidion + Nicidion megabalanicola sp. nov. Mandibles flat, MxVI absent or present. Subacicular hook darkest colour shade on most of the length of hook, but colour more

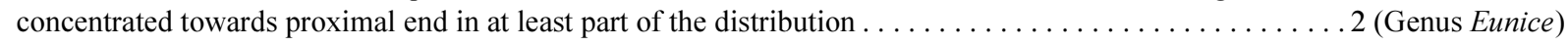

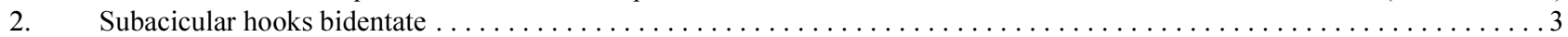

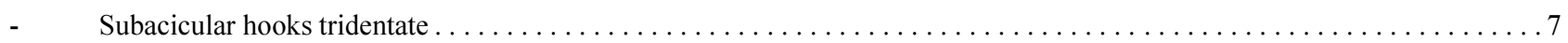

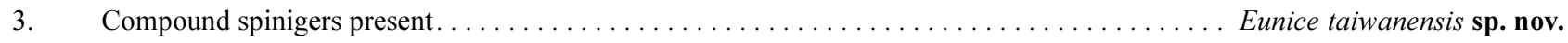

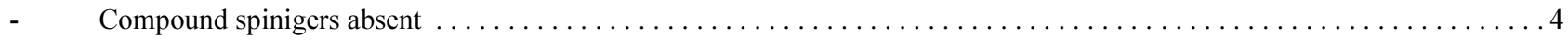

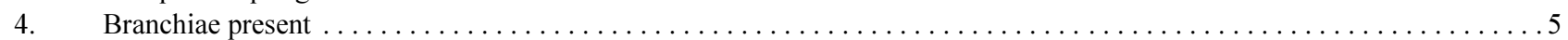

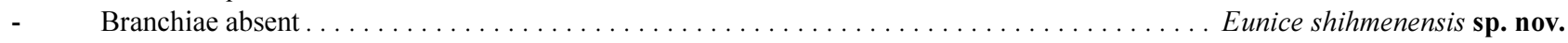

5. Branchiae first present before chaetiger $10 \ldots \ldots \ldots \ldots \ldots \ldots \ldots \ldots \ldots \ldots \ldots \ldots \ldots \ldots \ldots \ldots \ldots \ldots \ldots$ Euce reticulata sp. nov.

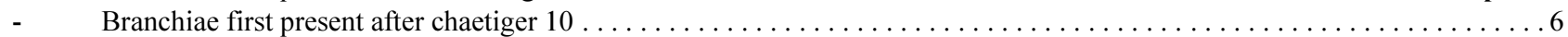

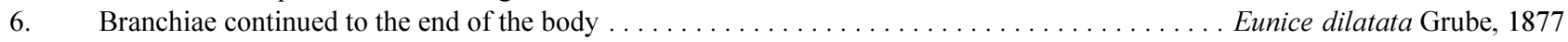

- $\quad$ Branchiae terminating near the middle of the body ......................... Eunice jihueiensis sp. nov.

7. Branchial filaments bimodal distribution; parapodia dorsal cirri with distinct long moniliform articulations.............

Eunice annulicirrata Miura, 1986 